\title{
Challenges Caused by the COVID-19 Quarantine for Families Raising Children with Disabilities: Compatibility Between Working from Home and Childcare
}

\author{
Laura Gardziuleviciene, MA \\ Association "Help the Children", Lithuania \\ Agota Giedre Raisiene, Prof. Dr. \\ Klaipeda University, Lithuania
}

Doi:10.19044/esj.2021.v17n35p22

Submitted: 21 July 2021

Accepted: 28 September 2021

Published: 31 October 2021

\author{
Copyright 2021 Author(s) \\ Under Creative Commons BY-NC-ND \\ 4.0 OPEN ACCESS
}

Cite As:

Gardziuleviciene L. \& Raisiene A.G. (2021). Challenges Caused by the COVID-19 Quarantine for Families Raising Children with Disabilities: Compatibility Between Working from Home and Childcare. European Scientific Journal, ESJ, 17 (35), 22.

https://doi.org/10.19044/esj.2021.v17n35p22

\begin{abstract}
Parents with children having special needs go through extremely difficult emotional, psychological experiences and physical fatigue due to unavailability of help and lack of access to social services. The COVID-19 pandemic has worsened the situation since the need for cohesion and the importance of social responsibility were not addressed well by the public authorities. The unavailability of help is believed to have plunged parents even further into exclusion. If before the pandemic, parents felt stigmatized, the situation after the COVID-19 pandemic became significantly worse. Thus, with the help of the phenomenological research, we aimed to reveal the challenges faced by families raising children with disabilities in combining aspects of work and childcare, by analyzing the attitudes and experiences of the respondents. The study is relevant for both public authorities and parents raising children with special needs in the context of developing social inclusion and family support network respectively.
\end{abstract}

Keywords: Working from home; childcare; parents of disabled children; COVID-19 challenges 


\section{Introduction}

The COVID-19 quarantine and its impact on humanity is a unique phenomenon (Durosini, Triberti, Savioni, \& Pravettoni, 2020). The government representatives kept people informed on the COVID-19 pandemic, rigorous restrictions were put into place, where people were encouraged to keep physical distance, wear masks, avoid communicating with more than several households (Nwachukwu, 2021). Due to limitations in physical contact, child daycare centers, child busyness centers, and other institutions providing services to children and their families were forced to close (Gadermann, Thomson, Richardson, Gagné, McAuliffe, Hirani \& Jenkins, 2021). Having closed elementary schools, children required care at home, and this inevitably increased the burden for their parents (Yamamura \& Tsustsui, 2021). A very difficult challenge proved to be the remote learning for children when parents needed to become more involved in the child's educational environment and at the same time combine their job and childcare commitments.

There is evidence that the COVID-19 pandemic caused social isolation (e.g., Dukes \& Berlingo, 2020; Cheng, Mendolia, Paloyo, Savage, \& Tani, 2021; Berard, Rattaz, Peries, Loubersac, Munir, \& Baghdadli, 2021). The pandemic especially sharpened the situation for people with disabilities, including challenges with availability of help and assistance, and lack of social inclusion. Families raising children with disabilities experienced a lot of negative impacts due to the unavailability of help (Yates \& Dickinson, 2021). Mothers, in particular, were involved more in family support processes by organizing remote learning, carrying out childcare, household chores all the while having commitments in their jobs, which caused an emergence of stress, fatigue, and disappointment (Neece, McIntyre \& Fenning, 2020; Hjálmsdóttir \& Bjarnadóttir, 2021). During quarantine, only a minority of parents were able to get involved in new activities, change jobs, solve existential crises, and experience emotional well-being, e.g., taking part in altruistic activities (Durosini et al., 2020).

As research shows, long-term isolation at home may have a long-term negative impact on families' emotional wellbeing, especially in families raising children with special needs (Shorey, Lau, Tan, Debby \& Ramkumar, 2021). The availability of social integration for families with members having special needs was obvious even before the pandemic. However, COVID-19 has shown just how big the exclusion of disabled people is during times of cataclysm (Blanck, 2020). Normally, politicians declare an effort to provide institutional help for the most socially vulnerable groups. Nevertheless, during the pandemic, people with disabilities remained outside of the government's focus. The disabled and their family members were left isolated two-fold: on the one hand, naturally isolated due to their disability, on the other hand, due 
to the government's instructions to close all social service institutions and the requirement for all citizens to remain home, limiting their social circle to a minimum. COVID-19 has revealed that governmental institutions are not prepared to apply means of social assistance in critical circumstances. Nevertheless, only assumptions can be made about the real work and life experience of parents with disabled children during the pandemic due to a lack of research on the problem. In this regard, our study aims to disclose the challenges of combining remote work and caring for a child with disabilities. A semi-structured interview method was used to find out the experiences of the informants without limiting their expression of opinion and not directing the respondents to answer with closed-type questions.

The article consists of four parts: a review of research on the challenges of families raising children with disabilities during the COVID-19 quarantine; aspects of compatibility between childcare and remote work in the context of COVID-19 pandemic; the methodology of empirical study, and the analysis of the interview results. At the end of the article, findings are set out.

\section{Social exclusion during the COVID-19 quarantine}

COVID-19 pandemic has made an already difficult situation and lack of availability of help for people with disabilities even more acute. Earlier pandemics have shown that public health problems and social exclusion are especially exposed during huge epidemics and influence the evolution of humanity (Yates \& Dickinson, 2021). The COVID-19 pandemic has strengthened social inequality and exposed the lack of effectiveness of the assistance system. Research shows that political measures dedicated to fighting COVID-19, i.e., closed institutions, remote work, etc. conform to social isolation (Cheng et al., 2021). Government representatives who influence social policy and make responsible decisions did not contribute to creating an inclusive society in their countries (Blanck, 2020). What is more, though social issues require more financial and human resources in crisis time, additional funding from the budget and other financial support was redirected to support businesses.

Scientists have determined that people who are left excluded from society due to their special needs are more affected by stress, which negatively influences also the health and behavior of their family members(Rigles, 2019). A margin between active society and vulnerable social groups is ever increased in the time of the pandemic (Dukes \& Berlingo, 2020). Long-term isolation at home causes long-term effects that have a significant impact on the emotional well-being of families, especially those raising children with disabilities (Shorey et al., 2021). Parents' social isolation directly affects the disabled child's development regardless of the type of disability Nevertheless, inadequate behavior is mostly observed in children with psychosocial 
disabilities. Educating parents on the aspects of their child's disability and collaboration with children's health and education professionals is no less important than diagnosing the child and appointing appropriate treatment (McConnell \& Savage, 2015; McConkey, Ohagan, \& Corcoran, 2021). To ensure the successful functioning of the family, a balance in all areas of life is key. Here, the way to improve the well-being of parents with disabled children as well as to reduce their stress and fatigue is psychosocial support.

In 2010, Lithuania ratified a United Nations Convention on the Rights of Persons with Disabilities, committing to create conditions and ensure availability for people with disabilities and their families to actively participate in education, culture, healthcare, labor market, and other societal processes. Nevertheless, social exclusion remains one of the fundamental issues for families raising children with disabilities, caused by a negative attitude towards them, condemnation, pity, and similar reactions from society. Such attitude influences the manifestation of the feeling of guilt in parents, which is caused by unpredictable child behavior and negative reactions from bystanders. As a result, parents usually choose exclusion and less participate in public life (McGarty, 2020). Limited accessibility of help and untimely psychosocial help to parents with disabled children negatively influence their life quality and reduce their participation in public life. During the COVID-19 pandemic, all families survived difficult moments, but the situation was more extreme in families raising children with more severe disabilities.

\section{Challenges of families raising children with special needs during COVID- 19 quarantine}

The pandemic unbalanced the everyday life of families, which was evident by worsened mental health and stress due to social isolation (Cost, Crosbie, Anagnostou, Birken, Charach, Monga, Kelley, Nicolson, Maguire, Burton, Schachar, Arnold \& Korczak, 2021). The entire world needed to adapt to the new situation because of the widespread virus. Research has shown that in the United Kingdom, 28 percent of parents who were quarantined were diagnosed with mental disorders, compared to 6 percent of those who did not experience hard quarantine restrictions (Nwachukwu, 2021). Families raising children with disabilities often benefit from various services which were disrupted during the pandemic, resulting in these families experiencing an extremely negative impact due to the lack of help availability.

The COVID-19 pandemic caused psychosocial consequences which outside of the quarantine period were addressed to and resolved by mental health specialists or social service institutions (Nwachukwu, 2021). Because of quarantine, a necessity of remote services was evident as parents raising children with disabilities were only ensured with partial service availability and continuity (Shorey et al., 2021). During the pandemic, children spent a 
significant amount of time using digital technologies. Meanwhile, parents aimed to ensure the family's emotional stability and children's mental health, thus they needed to discover ways to control negative emotions, maintain adequate levels of physical activity and keep up the family members' motivation (Shuai, He, Zheng, Wang, Qiu, Xia, Cao, Lu, \& Zhang, 2021). During the COVID-19 outbreak, changes in families were observed. Parents, especially mothers, dedicated more time for childcare and less to their personal needs (Ribeiro, Janzen, Passarini \& Vanzella, 2021; Papadopoulos, 2021). During the COVID-19 pandemic, more than 300 million people needed to participate in remote learning (Alsadoon \& Turkestani, 2020). Parents had to assist children with their education processes, requiring combining this assistance with their own job commitments and housework. Quarantine disrupted systems that allowed to maintain the mental health and emotional wellbeing of families (Gadermann et al., 2021). The quarantine restrictions were only softened in some countries (Wilson, 2020). However, even in these countries, e.g., in France, people with disabilities could not receive governmental institution services on their full scale: around a third of these people remained at home and kept compliant with safety requirements and recommendations (Berard et al., 2021).

According to research, public politics and education representatives had to foresee the measures and decisions which would balance out the risk of infection and allow children to learn at school, as remote learning caused deterioration of children's mental health (Cost et al., 2021; Sieberer, Kaman, Erhart, Devine, Schlack \& Otto, 2021; Shorey et al., 2021). The pandemic has clearly shown that even economically developed countries, such as the United States of America are not fully prepared for extreme situations, especially handling the difficulties experienced by citizen groups with partial possibilities (Baweja et al., 2021).

Researchers determined five aspects that had the biggest impact on people's mental health during quarantine. These are the following: i) length of quarantine; ii) fear of infection; iii) frustration and boredom; iv) insufficient resources; v) lack of information (Durosini et al., 2020; Brooks, Webster, Smith, Woodland, Wessely \& Greenberg, 2020). Some of these aspects depend on every individual while others are closely related to opportunities provided by the individual's environment. In Lithuania, for example, people with disabilities were unable to participate in some busyness activities, while children with special needs could not attend educational institutions for almost the whole pandemic (Resolution of the Government of the Republic of Lithuania No. 1226, 4th of November 2020 "On the announcement of quarantine in the territory of the Republic of Lithuania"). A period like this lasted more than six months. Parents who decided against letting their children with disabilities attend education institutions could apply for a certificate of 
incapacity or received unemployment checks. Families raising children with disabilities were provided with medical, social, and education services. Assistance was oriented to particular segments which better respond to a child's needs. However, to take care of the child, complex help is required for parents as well. Even before the pandemic, families raising children with disabilities faced a lack of availability and accessibility of individual help, and lack of information in Lithuania though families have the right to address governmental institutions for assistance and necessity of one or another service according to legal documents. Therefore, the COVID-19 pandemic has highlighted the severity of problems of social exclusion for families raising children with disabilities.

\section{Working from home and childcare in the context of the COVID-19 pandemic}

Parents' participation in the labor market directly affects the family's emotional wellbeing (Stefanidis \& Strogilos 2020). During the pandemic, remote work has become a challenge due to altered work conditions (Zamarro $\&$ Prados, 2021). Working from home changed people's daily routine, home environment, and busyness.

During the COVID-19 pandemic, education, health management, hobbies, and sports, leisure activities became very limited or completely unavailable (Durosini et al., 2020). Families experienced anxiety about possible financial instability as not all employers could offer the possibility to work remotely. Moreover, some of the employers relieved laid off their employees when the company's activities stopped (Baweja et al., 2021). It was natural that working people who have children experienced more financial challenges compared to childless people. Nevertheless, the most difficult situation fell upon people with children who lost their jobs.

A huge challenge for parents proved to be remote learning (Baweja et al., 2021). Parents had to learn to manage their time and energy resources more effectively. Although in most of the countries, children with disabilities were allowed to learn in the contact method, families whose children had additional diseases, or a compromised immune system avoided using services that required physical contact to prevent being infected with the virus. Therefore, family members were the ones responsible for educating, caring for the child with a disability, and meeting the child's other needs.

It is significant to highlight that grandparents have a high impact on households and contribute to the economic, social, and emotional life of the family by participating in childcare (Cantillon, Moore \& Teasdale, 2021). Before the pandemic, grandparents helped with caring for children with disabilities. However, during the pandemic, family members that were not a part of the same household could not participate in childcare anymore. The 
pandemic increased differences between genders regarding childcare and even more burdened people that not only worked remotely but also carried the responsibility for the household (Yamamura \& Tsustsui, 2021). Mothers take upon the burden of working from home and caring for children while fathers are keener on working at the office and contribute less to childcare (Cheng et al., 2021). Mothers organize the daily routine, which included combining their children's remote learning, childcare, and household chores, which resulted in the emergence of stress, fatigue, and frustration (Neece et al., 2020; Hjálmsdóttir \& Bjarnadóttir, 2021). Increased burned caused stress not only for the woman but for her whole family (Yamamura \& Tsustsui, 2021; Fodor, Gregor, Fodor, et al., 2021). During quarantine, only a small portion of parents was able to participate in new activities, switch jobs, spend more time with their families, see deeper into children's needs, and survive existential crises (Durosini et al., 2020).

Compatibility of work and childcare during quarantine has become a complicated process for families with children that develop regularly. However, it has become extremely hard for families raising children with disabilities.

\section{Research methodology}

The research data was gathered using a semi-structured interview. The phenomenological approach was chosen because the struggles of families where one or more members have disabilities are poorly researched in the context of the pandemic.

In the research, parents with disabled children were interviewed. A mandatory condition to participate in the research was that at minimum one of the parents have a part-day or full-day job. Respondents were invited to participate in the research via special groups in social media using the snowball method. This method was chosen to ensure that any parent who has disabled children in Lithuania could have an opportunity to be selected into the sample of the research. The limitations of the research sample were only caused by the willingness of the potential respondents - people were asked to participate in the research voluntarily.

Thus, the selection of research participants was based on three criteria: 1) one or more children with disabilities in the family; 2) at least one of the parents being employed; 3 ) children in the family are of school age and were learning from home during quarantine. All these criteria were met by fifteen families that agreed to share their experiences.

The age of the informants was from 26 to 47 years. Eight of the questioned families raise two children, three families raise three or more children, and four families raise one child with special needs who requires special care. 
The interview data was gathered via direct and remote meetings and phone calls. The average length of an interview was 40 minutes. To ensure confidentiality, the informants ${ }^{6}$ names were replaced with codes. The informants' characteristics are presented in Table 1.

Table 1. Sociodemographic characteristics of the informants.

\begin{tabular}{|c|c|c|c|c|c|}
\hline Code & Gender & Age & $\begin{array}{c}\text { Both } \\
\text { parents } \\
\text { working }\end{array}$ & $\begin{array}{c}\text { Working } \\
\text { parent }\end{array}$ & Work nature \\
\hline S1 & Female & 40 & & father & mental \\
\hline $\mathrm{S} 2$ & female & 26 & + & & physical \\
\hline S3 & Female & 40 & + & & mental \\
\hline S4 & Female & 39 & + & & mental \\
\hline S5 & Female & 37 & + & & mental \\
\hline S6 & Male & 42 & + & & physical - mental \\
\hline S7 & Female & 38 & + & & mental \\
\hline S8 & Female & 30 & + & & physical - mental \\
\hline S9 & Female & 27 & & father & physical \\
\hline S10 & Male & 45 & + & & mental \\
\hline S11 & Male & 46 & + & & mental \\
\hline S12 & Female & 46 & & father & physical - mental \\
\hline S13 & Female & 26 & & mother & mental \\
\hline S14 & Female & 32 & + & & physical \\
\hline S15 & Female & 47 & & mother & mental \\
\hline
\end{tabular}

Source: the authors' research.

All research participants were informed about the goal of the research, use of their data, and assurance of confidentiality. During the research, the anonymity of data was ensured, and principles of voluntary participation, privacy, confidentiality, and personal respect were followed.

After the interview, the gathered data was transcribed, analysed, and formed into semantic units, then, grouped into categories and subcategories. The conclusions were formed using the inductive method.

\section{Analysis}

The interview results have shown that during quarantine, role conflict has become more severe. Families were affected by both external pressure and internal contradictions. Due to pressure from employers and children's educational institutions, as well as because of lost access to the majority of social help services which before the pandemic were provided by special institutions, parents experienced internal tensions when deciding which of the two most important roles to take on - employee or parent. In cases of more complex children's disabilities, remote work and childcare were completely incompatible, according to the interviewed. Therefore, one of the parents usually had to sacrifice the job to take care of their child. 
Table 2. Compatibility of work and childcare during the COVID-19 pandemic.

\begin{tabular}{|c|c|c|}
\hline Category & Subcategories & Supporting statements \\
\hline \multirow[t]{10}{*}{$\begin{array}{l}\text { Compatibility } \\
\text { of remote } \\
\text { work and } \\
\text { childcare }\end{array}$} & \multirow[t]{8}{*}{$\begin{array}{l}\text { Role conflict: } \\
\text { parents or } \\
\text { employees? }\end{array}$} & $\begin{array}{l}\text { "<... I missed the understanding that there was a } \\
\text { disabled child at home and both parents are working. } \\
\text { In general, no one took working parents into } \\
\text { consideration, only insisted on parents to teach their } \\
\text { children while only giving instructions remotely" (S8) }\end{array}$ \\
\hline & & $\begin{array}{c}\text { "<...> it is difficult to combine remote education, } \\
\text { child's development, exercise, work and on top of that, } \\
\text { find time to rest" (S14) }\end{array}$ \\
\hline & & $\begin{array}{c}\text { "<.. > the most difficult part was that the workday did } \\
\text { not have clear working hours, most important and } \\
\text { difficult tasks were postponed to the night, when it is } \\
\text { possible to focus, work in silence. During the day, as a } \\
\text { mother I felt stressed out because everyone's needs } \\
\text { had to be met, daily routine kept (returning from work, } \\
\text { cooking etc.)" (S14) }\end{array}$ \\
\hline & & $\begin{array}{c}<\ldots>\text { me and my husband shared childcare half a } \\
\text { day each. In the morning, I was at work and after } \\
\text { lunch, my husband was at work" (S2) }\end{array}$ \\
\hline & & $\begin{array}{c}<\ldots>\text { the lack of childcare services was very evident, } \\
\text { as one cannot take care of the child with quality while } \\
\text { working, you are only meeting his physical needs as } \\
\text { you don't have any time to even think about his } \\
\text { education and development" (S5) }\end{array}$ \\
\hline & & $\begin{array}{c}\text { "<... it was extremely difficult to combine work and } \\
\text { childcare" (S6) }\end{array}$ \\
\hline & & $\begin{array}{l}\text { " }<\ldots>\text { one of the parents has to make a sacrifice, as } \\
\text { work and caring for a child with a disability are } \\
\text { completely incompatible. I applied for incapacity for } \\
\text { work and we obviously felt it financially" (S12) }\end{array}$ \\
\hline & & $\begin{array}{c}\text { "<... }>\text { I stayed at home with the children to allow my } \\
\text { husband to work full-time" (S2) }\end{array}$ \\
\hline & \multirow{2}{*}{$\begin{array}{l}\text { Increased } \\
\text { burden of } \\
\text { personal } \\
\text { responsibilities } \\
\text { due to the } \\
\text { closure of } \\
\text { education and } \\
\text { social care } \\
\text { institutions }\end{array}$} & $\begin{array}{c}\text { "<.. > continuous sitting at home with children where } \\
\text { you not only have to be a mother, but also a teacher } \\
\text { and have to take care of everything... And also, a little } \\
\text { daughter who requires full assistance, drains you both } \\
\text { physically and emotionally"(S9) }\end{array}$ \\
\hline & & $\begin{array}{l}\text { " }<\ldots>\text { no one took working parents into } \\
\text { consideration, only insisted on parents teaching the } \\
\text { child while only giving instructions remotely" (S10) }\end{array}$ \\
\hline
\end{tabular}

Source: the authors' research.

The interview has shown that in families where only one parent is working and the other is taking care of the child, parents experience psychoemotional separation. The especially complicated situation was faced by 
parents raising children with psychosocial disabilities. These children require constant care and special attention. The tension, stress, fatigue, and guilt felt by the parents raised significant challenges for the emotional stability of the whole family. Meanwhile, families, where both parents were working during quarantine, did not feel a destructive effect on their relationships but only mentioned increased social isolation. Therefore, having a job bears not only financial security for parents raising children with disabilities. Unfortunately, during the COVID-19 pandemic, families with disabled children experienced increased social exclusion, psycho-emotional and physical fatigue, relationship issues due to the unavailability of social help.

Table 3. The impact of quarantine on the psycho-emotional wellbeing of parents raising children with disabilities.

\begin{tabular}{|c|c|c|}
\hline Category & Subcategories & Supporting statements \\
\hline \multirow[t]{6}{*}{$\begin{array}{l}\text { The lack of } \\
\text { social help }\end{array}$} & \multirow[t]{3}{*}{ Social exclusion } & $\begin{array}{l}"<\ldots>\text { during quarantine, I understood that work for } \\
\text { me is an opportunity to get out of home, change } \\
\text { environment and run away from daily routine " (S3) }\end{array}$ \\
\hline & & $\begin{array}{c}\text { "<... I miss colleagues, morning coffee gatherings. } \\
\text { Work is a great opportunity to get out of home routing } \\
\text { and change environment. I could not work remotely all } \\
\text { the time; it is exhausting and separates me from } \\
\text { people"(S1) }\end{array}$ \\
\hline & & 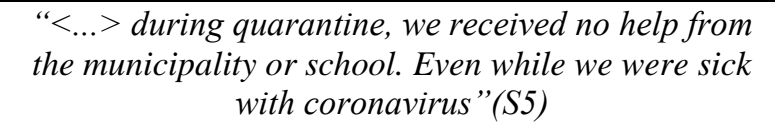 \\
\hline & \multirow[t]{3}{*}{$\begin{array}{c}\text { Psycho-emotional } \\
\text { fatigue }\end{array}$} & $\begin{array}{c}\text { "<... I was always afraid my daughter would not } \\
\text { survive being infected. Her immune system is very } \\
\text { weak" (S15) }\end{array}$ \\
\hline & & $\begin{array}{c}\text { "<...> I lacked quality rest and sleep, change of } \\
\text { environment, and some time only for myself. I would } \\
\text { have also been very grateful for help with tidying up } \\
\text { the home. " (S2) }\end{array}$ \\
\hline & & $\begin{array}{c}{ }^{\prime}<\ldots>\text { I had to take sedatives as psychological tension } \\
\text { was unbearable, I sought specialists' help " (S7) }\end{array}$ \\
\hline
\end{tabular}

Source: the authors' research.

During quarantine, unusual challenges were caused by remote learning. Education of normal development children was transferred to remote learning on a somewhat full scale. However, the education of children with disabilities was transferred to their parents. Some parents were infected with coronavirus or had to self-isolate but did not receive any help from the pedagogues even in that case.

Children with disabilities also lacked healthcare and special help during quarantine, which is especially important to the child's development. 
Table 4. Lack of education and healthcare services for children with disabilities.

\begin{tabular}{|c|c|c|}
\hline Category & Subcategories & Supporting statements \\
\hline \multirow[t]{5}{*}{$\begin{array}{l}\text { Necessity of } \\
\text { services for } \\
\text { the child }\end{array}$} & \multirow[t]{3}{*}{ Education } & $\begin{array}{c}\text { "<...> education was not carried out, maybe due to } \\
\text { our fault as we did not educate our child on our own " } \\
(\text { S1O) }\end{array}$ \\
\hline & & $\begin{array}{c}<\ldots>\text { it was very difficult, especially for my daughter } \\
\text { with special needs. I applied for incapacity for work in } \\
\text { order to assist with education processes"(S4) }\end{array}$ \\
\hline & & $\begin{array}{c}\text { "<...> I felt guilty that due to the amount of work I } \\
\text { could not provide my child with enough attention and } \\
\text { his education did not take place" (S7) }\end{array}$ \\
\hline & \multirow[t]{2}{*}{ Special help } & $\begin{array}{l}\text { " }<\ldots>\text { we really lacked procedures and occupations } \\
\text { for the child which were discontinued due to COVID- } \\
19 \text { both at school and town's education center " (S12) }\end{array}$ \\
\hline & & $\begin{array}{c}\text { " }<\ldots>\text { we require constant services from a } \\
\text { physiotherapist, occupational therapist, music } \\
\text { therapist, psychologist and speech therapist. We only } \\
\text { had one meeting a year and they are mandatory for the } \\
\text { child's development" (S7) }\end{array}$ \\
\hline
\end{tabular}

Source: the authors' research.

However, in some cases, the pandemic brought positive consequences. The changes happening in the world forced people to slow down the pace of life and spend more time with their families: " $<\ldots>$ it seems that I can fit a lot in my day. Simple things started to make me happy - a short walk, driving somewhere, coffee in the car. I think that there were not a lot of education in my time with children, but we spent our time together nicely..." (S5). People going through difficult experiences often experience existential changes and internal transformations. The informants in our research state that " $<\ldots>$ in spring, when full quarantine was announced and we had to educate our child at home, I found that there is more time for the child's needs, I better knew my child..." (S13); “< ..> we spent more time with the family..." (S10).

In conclusion, both negative and positive aspects influenced the informants' compatibility between work and childcare during COVID-19. 


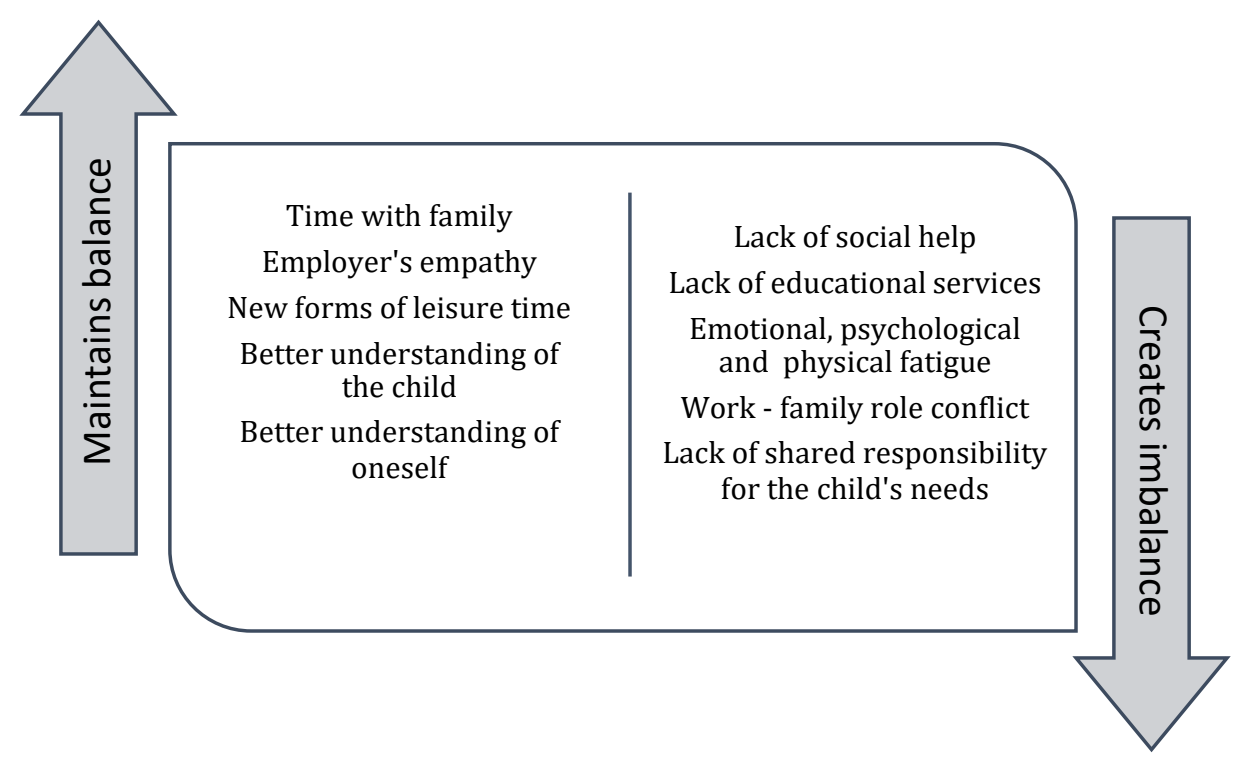

Picture 1. Aspects influencing the compatibility between work from home and caring for children with disabilities.

Source: the authors.

COVID-19 has highlighted the complex situation of families raising children with disabilities and the unpreparedness of governmental institutions to help parents in an extreme situation.

\section{Conclusion}

COVID-19 pandemic is an extremely difficult period for families with disabled children. Families where one or more children have special needs experience bigger physical, emotional, and psychological fatigue than typical development children having families. Our research revealed that in the time of quarantine, parents' responsibilities and duties dramatically increased whereas families' daily routines became significantly unbalanced. The research shows that childcare duties and working from home are almost incompatible as a child with disabilities requires special attention and care.

The research has determined that parents' participation in the labor market reduces the risk of social exclusion: having a job is not only required to ensure financial stability but also increases the family's wellbeing.

The situation when social services were unavailable during quarantine most negatively impacted families raising children with psycho-social disabilities. The informants' experiences have revealed that the education of children with severe disabilities or very high special needs was left completely for the parents to carry out. 
According to our research, parents found positivity in the changed situation at the start of the COVID-19 pandemic. At the beginning of the quarantine, some families were happy with the opportunity to spend more time with their children and better understand their children's needs. However, with time these families began to feel the negative consequences of social isolation as well especially the consequences of the unavailability of social services.

Our study does not claim to draw broad conclusions; however, the insights of the research can be seen as a step towards a better understanding of how families with disabled children live in the time of the current cataclysm. The key message of our study is that if social policymakers do not take into account the situation of families with disabled children, with the continuation of the pandemic and the lack of necessary social assistance, this social group may experience a complete collapse as economically viable members of society.

\section{References:}

1. Alsadoon, E., Turkestani, M. (2020). Virtual Classrooms for Hearingimpaired Students during the COVID19 Pandemic. Romanian Journal for Multidimensional Education, 12(1), 1-8. DOI:10.18662/rrem/12.1sup2/240.

2. Baweja, R., Brown, S.L., Edwards, E.M., \& Murray, M.J. (2021). COVID-19 Pandemic and Impact on Patients with Autism Spectrum Disorder. Journal of Autism and Developmental Disorders. DOI: https://doi.org/10.1007/s10803-021-04950-9.

3. Berard, M., Rattaz, C., Peries, M., Loubersac, J., Munir, K., \& Baghdadli, A. (2021). Impact of containment and mitigation measures on children and youth with ASD during the COVID-19 pandemic: Report from the ELENA cohort. Journal of Psychiatric Research, 137, 73-80. DOI: https://doi.org/10.1016/j.jpsychires.2021.02.041.

4. Blanck, P. (2020). Disability Inclusive Employment and the Accommodation Principle: Emerging Issues in Research, Policy, and Law. Journal of Occupational Rehabilitation, 7(30), 505-510. https://doi.org/10.1007/s10926-020-09940-9.

5. Brooks, S. K., Webster, R. K., Smith, L. E., Woodland, L., Wessely, S., \& Greenberg, N. (2020). The psychological impact of quarantine and how to reduce it: rapid review of the evidence. The Lancet, 395, 912 - 920. DOI: https://doi.org/10.1016/S0140-6736(20)30460-8 PMID: 32112714.

6. Cantillon, S., Moore, E., \& Teasdale, N. (2021). COVID-19 and the Pivotal role of Grandparents: Childcare and income Support in the UK and South Africa. Feminist Economics, 27(1-2), 188-202. DOI: 10.1080/13545701.2020.1860246. 
7. Cheng, Z., Mendolia, S., Paloyo, A.R., Savage, D.A., \& Tani, M. (2021). Working parents, financial insecurity, and childcare: mental health in the time of COVID-19 in the UK. 13. Review of Economics of the Household, 19, 123-144. DOI: https://doi.org/10.1007/s11150020-09538-3.

8. Cost, K.T., Crosbie, J., Anagnostou, E., Birken, C.S., Charach, A., Monga, S., Kelley, E., Nicolson, R., Maguire, J.L., Burton, Ch. L., Schachar, R. J., Arnold, P.J., \& Korczak, D.J. (2021). Mostly worse, occasionally better: impact of COVID-19 pandemic on the mental health of Canadian children and adolescents. European Child \& Adolescent Psychiatry. DOI: https://doi.org/10.1007/s00787-02101744-3.

9. Durosini, I., Triberti, S., Savioni, L., \& Pravettoni, G. (2020). In the eye of a quiet storm: A critical incident study on the quarantine experience during the coronavirus pandemic. PLoS ONE, 16(2), e0247121. DOI: https://doi.org/10.1371/journal.pone.0247121.

10. Fodor, E., Gregor, A., Koltai, J., Kováts, E. (2021). The impact of COVID-19 on the gender division of childcare work in Hungary. European Societies, 23, $1 . \quad$ DOI: https://doi.org/10.1080/14616696.2020.1817522.

11. Gadermann, A. C., Thomson, K.C., Richardson, Ch. G., Gagné, M., McAuliffe, Hirani, S., \& Jenkins, E. (2021). Examining the impacts of the COVID-19 pandemic on family mental health in Canada: findings from a national cross-sectional study. BMJ Open, 11:e042871. DOI:10.1136/bmjopen-2020-042871 1.

12. Hjálmsdóttir, A., Bjarnadóttir, V. S. (2021). "I have turned into a foreman here at home": Families and work-life balance in times of COVID-19 in a gender equality paradise. Gender Work and Organization, 28, (1), 68-283. DOI: 10.1111/gwao.12552.

13. Lietuvos Respublikos Socialiniu paslangu istatymas. 2006 m. sausio 19 d. Nr. X-493. Available at: https://eseimas.lrs.lt/portal/legalAct/lt/TAD/TAIS.270342

14. McConkey, R., Ohagan, P. \& Corcoran, J. (2021). The need for and the impact of a family-centred intervention for parents of children with developmental disabilities: A model project in rural Ireland, in Proceedings of the 3rd International Electronic Conference on Environmental Research and Public Health - Public Health Issues in the Context of the COVID-19 Pandemic, MDPI: Basel, Switzerland, doi:10.3390/ECERPH-3-09023

15. McConnell, D. \& Savage, A. (2015). Stress and Resilience Among Families Caring for Children with Intellectual Disability: Expanding 
the Research Agenda. Current Developmental Disorders Reports, 2, 100-109 https://doi.org/10.1007/s40474-015-0040-z

16. Moloney, K., Moloney, S. (2020). Australian Quarantine Policy: From Centralization to Coordination with Mid-Pandemic COVID-19 Shifts. The American Society for Public Administration, 80(4), 671-682. DOI: 10.1111/puar.13224.

17. Neece, C., McIntyre, L. L., \& Fenning, R. (2020). Examining the impact of COVID-19 in ethnically diverse families with young children with intellectual and developmental disabilities. Journal of Intellectual Disability Research, 64(10). DOI: https://doi.org/10.1111/jir.12769.

18. Nwachukwu, P.T.T (2021). COVID-19 Lockdown and its Impact on Social-Ethics and Psycho- Social Support for Disability Care. Journal of Intellectual Disability - Diagnosis and Treatment, 9(1), 45-55. DOI: https://doi.org/10.6000/2292-2598.2021.09.01.6.

19. Papadopoulos, D. (2021). Mothers' Experiences and Challenges Raising a Child with Autism Spectrum Disorder: A Qualitative Study. Brain Sciences, $11,309$. DOI:https://doi.org/10.3390/brainsci11030309.

20. Ribeiro, F.S., Janzen, T.B., Passarini, L., \& Vanzella, P. (2021). Exploring Changes in Musical Behaviors of Caregivers and Children in Social Distancing During the COVID-19 Outbreak. Frontiers in Psychology, 12. DOI: 10.3389/fpsyg.2021.629768.

21. Shorey, S., Lau, L.S.T., Tan, J.X., Debby, E., \& Ramkumar, A. (2021). Families With Children with Neurodevelopmental Disorders During COVID-19: A Scoping Review. Journal of Pediatric Psychology, 2021, 1-12. DOI: 10.1093/jpepsy/jsab029.

22. Shuai, L., He, Sh., Zheng, H., Wang, Z., Qiu, M., Xia, W., Cao, X., Lu, L., \& Zhang, J. (2021). Influences of digital media use on children and adolescents with ADHD during COVID-19 pandemic. Globalization and Health, 17(48), DOI: https://doi.org/10.1186/s12992-021-00699-z.

23. Sieberer, U.R., Kaman, A., Erhart, M., Devine, J., Schlack, R. , \& Otto, Ch. (2021). Impact of the COVID-19 pandemic on quality of life and mental health in children and adolescents in Germany. European Child \& Adolescent Psychiatry. DOI: https://doi.org/10.1007/s00787-02101726-5.

24. Williams, K., Jacoby, P., Whitehouse, A., Kim, R., Epstein, A., Murphy, N.,

25. Wilson, K. (2020). The COVID-19 pandemic and the human rights of persons with mental and cognitive impairments subject to coercive 
powers in Australia. International Journal of Law and Psychiatry, 73. DOI: https://doi.org/10.1016/j.ijlp.2020.101605.

26. Yamamura, E., Tsustsui, Y. (2021). The impact of closing schools on working from home during the COVID-19 pandemic: evidence using panel data from Japan. Review of Economics of the Household, 19, 4160. DOI: https://doi.org/10.1007/s11150-020-09536-5.

27. Yates, S., Dickinson, H. (2021). Navigating Complexity in a Global Pandemic: The Effects of COVID-19 on Children and Young People with Disability and Their Families in Australia. Public Administration Review, DOI:10.1111/puar.13352.

28. Zamarro, G., Prados, M. J. (2021). Gender differences in couples' division of childcare, work and mental health during COVID-19. Review of Economics of the Household, 19, 11-40. DOI: https://doi.org/10.1007/s11150-020-09534-7.

29. Rigles, B. (2019). The Development of Health Lifestyles in Families Experiencing Disability. Journal of Family Issues, 40(7), 929-953. DOI: $10.1177 / 0192513$ X19831410

30. Dukes, Ch. \& Berlingo, L. (2020). Fissuring Barriers to Inclusive Education for Students with Severe Disabilities, Research and Practice for Persons with Severe Disabilities, 45(1),14-17. 